Jurnal Ilmu Ilmu Agribisnis: Journal of Agribusiness Science, 9(1), Februari 2021

\title{
ANALISIS BIAYA PASCA PANEN DAN NILAI TAMBAH PENGGILINGAN PADI DI KOTA TERPADU MANDIRI KABUPATEN MESUJI
}

\author{
(Analysis of Post Harvest Costs and Added Value of Rice Milling in Independent Integrated City, \\ Mesuji District)
}

\begin{abstract}
Ahmad Hafidz Afif Furqoni, Dwi Haryono, Sumaryo Gitosaputro
Jurusan Agribisnis, Fakultas Pertanian, Universitas Lampung. Jl. Prof. Dr. Soemantri Brodjonegoro No. 1, Bandar Lampung, 35145, e-mail : dwi.haryono@fp.unila.ac.id
\end{abstract}

\begin{abstract}
This study aims to determine post-harvest handling and the amount of post-harvest costs and to analyze the added value of the rice milling business in the Independent Integrated City of Mesuji. The research method used a survey method. The study was conducted in the villages of Tanjung Mas Mulya, Tanjung Mas Makmur, and Pangkal Mas Mulya, East Mesuji Sub-District. The samples of this research were farmers and agro-industries. The number of samples were 37 farmers in Tanjung Mas Mulya Village, 22 farmers in Pangkal Mas Mulya Village, and 9 farmers in Tanjung Mas Makmur Village, while the samples from agroindustries were 5 owners from Tanjung Mas Mulya Village, 4 from Pangkal Mas Mulya Village, and 2 from Tanjung Mas Makmur Village. Data collection was conducted from June to July 2019. The study results show that post-harvest handling by farmers was limited to transportation. The amount of harvest cost and post-harvest cost is IDR3,513,359.97 per hectare. The average value added in agro-industries using box dryer machines was IDR629.97 per kilogram of raw materials and IDR525.68 per kilogram of raw materials for agro-industries not using box dryer machines.
\end{abstract}

Key words : added value, post harvest, rice milling

\section{PENDAHULUAN}

Program transmigrasi merupakan bagian dari pembangunan nasional dan daerah di kawasan yang relatif tertinggal. Program ini bertujuan untuk pemerataan kesejahteraan, percepatan pembangunan wilayah hingga menyatukan bangsa Indonesia. Transmigrasi merupakan suatu program pemerintah untuk memindahkan penduduk dari suatu daerah padat ke daerah lain. Pembangunan kawasan transmigrasi juga dapat bersifat lintas sektor, baik ditingkat pusat, maupun di tingkat daerah (UU No. 29 Tahun 2009). Melalui Departemen Tenaga Kerja dan Transmigrasi yang selanjutnya disebut Depnakertrans pada tahun 2006 menggulirkan sebuah program yang bertujuan untuk mewujudkan tujuan-tujuan dari adanya transmigrasi yaitu program Kota Terpadu Mandiri atau dikenal dengan sebutan KTM di Indonesia (Firdaus dan Arizona 2013)

Menurut Buditama, Yuniati, dan Nurmayani (2017) Kota Terpadu Mandiri merupakan cara mengembangkan kawasan transmigrasi secara berkelanjutan mendasar pada potensi dan karakteristik yang dimiliki daerah tersebut.
Program ini dirancang untuk membangun daerah transmigrasi menjadi sebuah daerah agropolitan yang mengelola komoditas pertanian unggulan yang memiliki potensi besar di daerah transmigrasi dari hulu sampai ke hilir.

Pelaksanaan program KTM di Provinsi Lampung terbagi dalam tiga daerah. Mesuji terpilih menjadi salah satu daerah KTM dikarenakan lokasinya yang strategis dan telah dihuni oleh lebih dari 25 ribu transmigran lokal yang berasal dari berbagai wilayah di Indonesia. Wilayah ini memiliki potensi besar di bidang pertanian, baik di bidang tanaman pangan, maupun tanaman perkebunan. Komoditas unggulan dari pertanian di Kabupaten Mesuji adalah padi sawah.

KTM Mesuji merupakan daerah perekonomiannya masih sangat bergantung terhadap sektor pertanian. Permasalahan utama komoditas padi adalah kekurangan stok beras. Program swasembada beras yang terus digalakkan oleh pemerintah belum sepenuhnya membuahkan hasil. Penanganan pasca panen yang belum baik berakibat kepada susut hasil panen tinggi dan kualitas padi yang kurang baik disebabkan tidak tepatnya waktu panen. 
Badan Pusat Statistik pada tahun 2012 merilis data kehilangan hasil panen atau susut pada tanaman padi yang diakibatkan oleh ketidaksempurnaan penanganan pasca panen mencapai 20,51 persen. Rincian kehilangan hasil meliputi susut pada saat pemanenan sebesar 9,52 persen, penanganan pada saat perontokan bulir padi sebesar 4,78 persen, penanganan pada saat pengeringan gabah mencapai 2,13 persen, dan kehilangan hasil pada saat penggilingan sebesar 2,19 persen (Badan Pusat Statistik 2012).

Permasalahan lainnya adalah rendahnya pendapatan petani. Hal ini terjadi salah satunya dikarenakan rendahnya nilai tambah produk yang dinikmati oleh petani. Sebagian besar petani menjual produksi padinya dengan sistem tebasan, yaitu pembeli akan mendatangi lahan petani untuk bernegosiasi terkait harga jual dengan melihat kualitas produk hingga terjadilah kesepakatan harga. Proses kegiatan pasca panen selanjutnya sudah tidak dilakukan oleh petani sehingga nilai tambah yang dihasilkan dari kegiatan pasca panen tidak dirasakan oleh petani, sedangkan risiko kegagalan usaha lebih banyak terjadi pada proses budidaya yang tentu saja harus ditanggung oleh petani (Sihombing dan Sumarauw 2015).

Kegiatan pasca panen merupakan kegiatan yang menghasilkan nilai tambah yang dapat meningkatkan pendapatan. Kegiatan pasca panen berupa kegiatan pengeringan hingga penggilingan padi menjadi beras justru dilakukan oleh agroindustri penggilingan padi. Pengembangan agroindustri pada kegiatan pasca panen membutuhkan tenaga kerja dan teknologi yang menunjang kegiatan-kegiatan tersebut.

Kebutuhan akan tenaga kerja dan teknologi menjadikan petani di KTM Mesuji enggan untuk menjual produknya dalam bentuk beras dikarenakan nilai tambah yang rendah dan kebutuhan akan modal yang digunakan untuk menunjang penghidupan dan usahatani di musim selanjutnya, sehingga diperlukan analisis terkait nilai tambah yang dihasilkan pada usaha penggilingan padi untuk mengetahui seberapa besar nilai tambah yang dihasilkan.

Berdasarkan uraian diatas tujuan penelitian yang dilakukan yaitu: mengetahui penanganan pasca panen, besarnya biaya pasca panen produksi padi dan menganalisis nilai tambah yang dihasilkan pada usaha penggilingan padi di KTM Mesuji.

\section{METODOLOGI PENELITIAN}

Penelitian ini menggunakan metode survei. Penelitian dilaksanakan di Desa Tanjung Mas Mulya, Tanjung Mas Makmur, dan Pangkal Mas Mulya Kecamatan Mesuji Timur, Kabupaten Mesuji. Penentuan lokasi penelitian dilakukan secara sengaja (purposive) dengan pertimbangan bahwa Kecamatan Mesuji Timur merupakan pusat perkembangan program Kota Terpadu Mandiri di Kabupaten Mesuji. Pemilihan Kabupaten Mesuji sebagai lokasi penelitian juga tak lepas dari keadaan Kabupaten Mesuji sendiri sebagai Kota Terpadu Mandiri yang menjadi pusat pengembangan komoditas padi.

Responden yang menjadi penelitian untuk menghitung biaya pasca panen ini adalah petani yang membudidayakan tanaman padi pada Desa Tanjung Mas Mulya, Tanjung Mas Makmur, dan Pangkal Mas Mulya, selain itu juga untuk menghitung nilai tambah penggilingan padi, maka diperlukan responden dari agroindustri yang ada KTM Mesuji.

Penentuan jumlah sampel menurut pendapat Slovin dalam Sugiarto (2003) diperoleh total sampel pada penelitian ini berjumlah 68 petani dari total keseluruhan populasi sebanyak 580 petani. Perhitungan jumlah sampel untuk masingmasing desa di daerah penelitian dihitung menggunakan rumus alokasi proporsional Nazir (2011) dapat diketahui jumlah sampel pada tiaptiap desa yaitu untuk Desa Tanjung Mas Mulya sebanyak 37 responden, Desa Pangkal Mas Mulya sebanyak 22 responden, dan Desa Tanjung Mas Makmur sebanyak 9 responden.

Data yang dikumpulkan pada penelitian ini adalah data primer dan data sekunder. Data primer diperoleh dengan mengadakan pengamatan langsung ke tempat penelitian dengan melakukan wawancara menggunakan kuisioner. Data sekunder diperoleh dari lembaga/instansi terkait seperti Badan Pusat Statistik Provinsi Lampung. Badan Pusat Statistik Kabupaten Mesuji dan Kementerian Pertanian yang digunakan untuk memperkuat hasil penelitian yang didapatkan.

Metode yang digunakan untuk menjawab tujuan pertama mengenai biaya pasca panen menggunakan metode deskriptif. Analisis ini meliputi biaya pemanenan dan perontokan bulir padi, pengangkutan, pengeringan, dan penggilingan. Biaya-biaya pasca panen dihitung merujuk kepada biaya tenaga kerja diukur dengan 
Hari Orang Kerja (HOK), biaya sewa kendaraan, biaya bahan bakar kendaraan, dan biaya sarana prasarana yang digunakan selama kegiatan pasca panen, selain itu juga akan dipaparkan besaran susut hasil yang terjadi akibat beberapa perlakuan pasca panen di daerah penelitian.

Metode analisis kuantitatif mengetahui nilai tambah yang dihasilkan dari kegiatan pasca panen komoditas padi pada agroindustri penggilingan padi. Analisis ini menggunakan metode kuantitatif mengikuti teori Hayami (1987).

Kriteria nilai tambah :

1. Jika NT $>0$, berarti pengembangan agroindustri penggilingan padi memberikan nilai tambah yang hasilnya positif.

2. Jika NT $<0$, berarti pengembangan agroindustri penggilingan padi memberikan nilai tambah yang hasilnya positif.

Menurut Soekartawi (2000), Sebuah usaha dijalankan bertujuan untuk mengambil keuntungan dari usaha tersebut sehingga usaha dapat berlanjut, untuk mengetahui suatu usaha menguntungkan atau tidak secara ekonomi dapat dianalisis dengan menggunakan nisbah atau perbandingan antara penerimaan dengan biaya (Revenue Cost Ratio) yaitu :

$\mathrm{R} / \mathrm{C}=\mathrm{TR} / \mathrm{TC}$

(1)

Keterangan :

$\mathrm{R} / \mathrm{C}=$ Nisbah penerimaan dan biaya

$\mathrm{TR}=$ Total revenue atau penerimaan total $(\mathrm{Rp})$

$\mathrm{TC}=$ Total cost atau biaya total $(\mathrm{Rp})$

Kriteria pengambilan keputusan dalam menentukan apakah usaha dinyatakan menguntungkan atau tidak adalah :

1. Jika $\mathrm{R} / \mathrm{C}>1$, maka usaha penggilingan padi dinyatakan mengalami keuntungan

2. Jika $\mathrm{R} / \mathrm{C}<1$, maka usaha penggilingan padi dinyatakan mengalami kerugian

3. Jika $\mathrm{R} / \mathrm{C}=1$, maka usaha penggilingan padi dinyatakan mengalami impas.

\section{HASIL DAN PEMBAHASAN}

\section{Karakteristik Responden}

Karakteristik petani dan pengusaha penggilingan padi meliputi usia, tingkat pendidikan, pengalaman usahatani dan menjalankan usaha penggilingan padi, dan jumlah anggota keluarga petani serta pengusaha penggilingan padi. Berdasarkan hasil penelitian yang telah dilakukan, dapat diketahui bahwa petani padi sebagian besar berada pada usia 47-57 tahun sebanyak 42,65 persen, sedangkan pengusaha penggilingan padi sebagian besar berusia antara 40-45 tahun sebanyak 72,73 persen. Menurut Badan Pusat Statistik (2018) semua responden di daerah penelitian berada dalam usia produktif.

Tingkat pendidikan responden di daerah penelitian cukup beragam. Berdasarkan hasil penelitian dapat diketahui bahwa tingkat pendidikan petani padi di KTM Mesuji sebagian besar hanya lulusan Sekolah Dasar (SD) sebesar 51,47 persendan mayoritas keluarga responden memiliki jumlah anggota keluarga antara 3-4 orang dengan persentase 52,94 persen, bahkan pada pengusaha agroindustri penggilingan padi sebanyak 100 persen responden memiliki tanggungan rumah tangga antara 3-4 orang.

Pengalaman dalam berusahatani dan usaha penggilingan di daerah penelitian sangat beragam yaitu antara 5 hingga 38 tahun dengan rata-rata pengalaman berusahatani sebesar 24,57 tahun dan untuk pengusaha penggilingan padi di daerah penelitian yaitu antara 6 hingga 15 tahun dengan rata-rata pengalaman melaksanakan usaha agroindustri penggilingan padi sebesar 10,27 tahun. Budidaya tanaman padi yang dilakukan menggunakan sistem monokultur. Luas lahan yang dimiliki petani padi di daerah penelitian bervariasi yaitu antara 0,50 hektar hingga 3,50 hektar dengan status kepemilikan lahan sebagian besar adalah milik sendiri dan sebagian kecil lainnya sewa.

\section{Kegiatan dan Biaya Panen serta Pasca Panen}

Kegiatan panen dan pasca panen meliputi dari kegiatan pemanenan padi, kegiatan perontokan, pengangkutan, pengeringan, dan penggilingan. Proses pemanenan padi di KTM Mesuji dilaksanakan menggunakan alat combine. Mesin ini sudah meliputi kegiatan pemanenan dan perontokan sehingga akan lebih menghemat waktu. Sistem upah yang digunakan untuk kegiatan panen menggunakan sistem bagi hasil 10:1. Rata-rata bagi hasil sebesar 494,03 kg/ha. Pemanenan dilakukan setelah terjadi kesepakatan harga antara agen pembeli GKP (Gabah Kering Panen) dan petani setelah pengusaha tersebut 
memeriksa kualitas padi yang ditanam oleh petani sehingga dapat dinegosiasi harga jualnya.

Pengangkutan hasil panen padi yang dilakukan oleh para petani padi di Kecamatan Mesuji Timur menggunakan jasa ojek yang banyak tersedia dan menjemur pada musim panen. Biaya untuk satu karung GKP sebesar Rp8.000,00 hingga Rp20.000,00 disesuaikan dengan kondisi jalan yang akan dilalui oleh para pengojek. Rata-rata biaya pengangkutan yang dikeluarkan petani sebesar Rp821.604,50/ha dengan ongkos rata-rata sebesar Rp9.485,39/karung. Jasa ojek dengan sendirinya akan datang ke lahan petani ketika mengetahui ada petani yang akan melakukan panen sehingga petani tidak perlu memanggil jasa ojek. Jasa yang harus dibayarkan ditentukan oleh jasa ojek yang pertama kali datang ke lokasi panen.

Proses pengeringan gabah sebagian besar dilakukan oleh para agen atau para pengusaha penggilingan padi yang menerima dan membeli hasil panen dari para petani. Proses pengeringan gabah dilakukan sampai kadar air berkurang antara 14 persen hingga 16 persen. Cara memperhatikan apakah gabah sudah kering dapat menggunakan cara manual yaitu dengan melihat warnanya, apabila warnanya sudah kuning cerah, maka gabah sudah kering. Cara kedua dengan meremas di telapak tangan, gabah yang kering tidak akan menempel pada telapak tangan bila diremas. Cara yang ketiga dengan menggigit gabah. Gabah yang telah kering akan terasa lebih keras dibandingkan dengan gabah yang belum kering.

Biaya yang harus dikeluarkan agroindustri penggilingan padi sebesar Rp13.527.045,45 per musim untuk agroindustri yang melakukan pengeringan menggunakan bantuan cahaya matahari, sedangkan bagi agroindustri yang menggunakan mesin Box dryer biaya sebesar Rp1.830.681,82 per musim. Kegiatan penggilingan gabah juga tidak dilakukan oleh petani, melainkan dilakukan oleh pengusaha penggilingan padi yang tersebar di KTM Mesuji. Biaya yang dikeluarkan agroindustri dalam penggilingan padi sebesar Rp8.254.419,60 per musim. Biaya jasa penggilingan digunakan sistem bagi hasil dengan ketentuan 12:1, artinya dalam $12 \mathrm{~kg}$ beras yang dihasilkan, agroindustri mendapatkan bagian satu kilogram.

Berdasarkan kegiatan panen dan pasca panen yang dilaksanakan dan bagi hasil yang telah dikonversikan ke dalam rupiah, maka biaya keseluruhan yang harus dibayarkan oleh petani jika melaksanakan kegiatan panen dan pasca panen secara mandiri sebesar Rp3.513.359,97 per hektar. Biaya tersebut meliputi biaya panen dan perontokan yang dikonversikan ke dalam rupiah sebesar Rp1.664.708,19 per hektar, biaya pengangkutan sebesar Rp821.604,50 per hektar, biaya pengeringan sebesar Rp386.828,97 per hektar, dan biaya penggilingan dengan sistem bagi hasil sebesar 186,22 $\mathrm{kg}$ per hektar yang dikonvesikan ke rupiah sebesar Rp1.461.822,81 per hektar.

\section{Susut Hasil Pengeringan dan Rendemen Pasca Panen}

Rendemen adalah persentase dari berat beras yang dihasilkan dari proses penggilingan, sedangkan susut hasil adalah besarnya kehilangan bobot produk akibat adanya sebuah perlakuan. Klasifikasi susut hasil pengeringan di daerah penelitian menggunakan pengeringan Box Dryer dan juga yang menggunakan cara manual menggunakan bantuan cahaya matahari. Pengeringan dengan sinar matahari dan pengeringan menggunakan Box Dryer menghasilkan susut hasil yang lebih rendah dibandingkan dengan pengeringan menggunakan cahaya matahari langsung. Pengeringan menggunakan Box dryer menghasilkan sebesar 11 persen saja, sedangkan pengeringan menggunakan bantuan cahaya matahari menghasilkan susut hasil sebesar 13 persen hingga 14 persen. Berdasarkan data tersebut, dapat disimpulkan bahwa kegiatan pengeringan menggunakan mesin Box dryer lebih efektif dan efisien, hal ini disebabkan penggunaan mesin Box dryer membutuhkan waktu yang lebih singkat dan kualitas hasil pengeringan lebih baik dan merata.

Pada rendemen penggilingan menunjukkan bahwa sebanyak 45,45 persen agroindutri mempunyai rendemen hasil penggilingan sebesar 58 persen, sedangkan sebanyak 18,18 persen agroindustri mempunyai rendemen sebesar 59 persen, dan sebanyak 36,36 persen agroindustri sisanya menghasilkan rendemen sebesar 60 persen. Hasil tesebut menyatakan dengan kualitas gabah kering giling yang berbeda-beda dapat menghasilkan rendemen yang berbeda pula.

Tingkat kadar air yang dihasilkan dari proses pengeringan akan berpengaruh terhadap kualitas gabah yang akan digiling sehingga menghasilkan rendemen yang lebih tinggi. 
Tabel 1. Nilai tambah agroindustri penggilingan padi berdasarkan mesin yang digunakan di Kecamatan Mesuji Timur, 2019

\begin{tabular}{|c|c|c|c|}
\hline $\begin{array}{l}\text { No. Variabel } \\
\text { Output, Input dan Harga }\end{array}$ & & $\begin{array}{l}\text { Agroindustri dengan } \\
\text { mesin penggiling dan } \\
\text { mesin Box Dryer }\end{array}$ & $\begin{array}{c}\text { Agroindustri dengan } \\
\text { mesin penggiling } \\
\text { tanpa mesin Box } \\
\text { Dryer } \\
\end{array}$ \\
\hline 1. Output (Kg/musim) & A & & \\
\hline Beras & & 163.658 & 121.685 \\
\hline 2. Bahan baku (Kg/musim) & B & 306.475 & 240.363 \\
\hline 3. Tenaga Kerja (HOK/musim) & $\mathrm{C}$ & 50 & 103 \\
\hline 4. Faktor Konversi & $d=a / b$ & & \\
\hline Beras & & 0,53 & 0,51 \\
\hline 5. Koefisien Tenaga Kerja & $\mathrm{e}=\mathrm{c} / \mathrm{b}$ & 0,0002 & 0,0004 \\
\hline 6. Harga Output & $\mathrm{F}$ & & \\
\hline Beras & & $7.850,00$ & $7.850,00$ \\
\hline 7. Upah Rata-rata Tenaga Kerja (Rp/HOK) & G & $70.000,00$ & $70.000,00$ \\
\hline \multicolumn{4}{|l|}{ Pendapatan dan Keuntungan (Rp/Kg) } \\
\hline 8. Harga bahan baku & $\mathrm{H}$ & $3.425,00$ & $3.314,29$ \\
\hline 9. Sumbangan input lain & I & 136,93 & 134,15 \\
\hline 10. Nilai Output & $\mathrm{j}=\mathrm{d} \times \mathrm{f}$ & & \\
\hline Beras & & $4.191,90$ & $3.974,12$ \\
\hline 11. a. Nilai Tambah & $k=j-i-h$ & 629,97 & 525,68 \\
\hline b. Rasio Nilai Tambah & $1=(\mathrm{k} / \mathrm{j}) \times 100(\%)$ & $15,03 \%$ & $13,23 \%$ \\
\hline 12. a. Imbalan Tenaga Kerja & $\mathrm{m}=\mathrm{e} \times \mathrm{g}$ & 11,51 & 29,97 \\
\hline b. Bagian Tenaga Kerja & $\mathrm{n}=(\mathrm{m} / \mathrm{k}) \times 100(\%)$ & $1,83 \%$ & $5,70 \%$ \\
\hline 13. a. Keuntungan & $\mathrm{o}=\mathrm{k}-\mathrm{m}$ & 618,46 & 495,71 \\
\hline b. Tingkat keuntungan & $\mathrm{p}=(\mathrm{o} / \mathrm{k}) \times 100(\%)$ & $98,17 \%$ & $94,30 \%$ \\
\hline \multicolumn{4}{|l|}{ Balas Jasa Pemilik Faktor-faktor Produksi } \\
\hline 14. Marjin Keuntungan & $q=j-h$ & 766,90 & 659,83 \\
\hline a. Keuntungan & $\mathrm{r}=\mathrm{o} / \mathrm{q} \times 100 \%$ & $80,64 \%$ & $75,13 \%$ \\
\hline b. Tenaga Kerja & $\mathrm{s}=\mathrm{m} / \mathrm{q} \times 100 \%$ & $1,50 \%$ & $4,54 \%$ \\
\hline c. Input lain & $\mathrm{t}=\mathrm{i} / \mathrm{q} \times 100 \%$ & $17,85 \%$ & $20,33 \%$ \\
\hline
\end{tabular}

Kadar air yang rendah akan meminimalisir patah bulir pada gabah yang digiling, sehingga kualitas beras yang di produksi akan semakin baik, terlebih lagi dengan varietas muncul yang biasa digunakan oleh petani yang memiliki bentuk bulir sedikit bulat dan tidak panjang seperti bulir padi varietas lain, sehingga kadar air gabah harus diperhatikan dengan baik agar menghasilkan kualitas beras yang baik.

\section{Analisis Nilai Tambah}

Hayami dkk (1987) menyatakan bahwa nilai tambah adalah selisih antara komoditas yang mendapat perlakuan pada tahap tertentu dengan nilai korbanan yang digunakan selama proses berlangsung. Proses pengolahan dapat memberikan nilai tambah bagi pengolah dalam menghasilkan produk.

Analisis yang dilakukan terhadap responden agroindustri di Kecamatan Mesuji Timur dibagi dalam tiga kelompok desa. Kelompok pertama yaitu Desa Tanjung Mas Mulya sebanyak lima orang responden. Kelompok kedua yaitu Desa Tanjung Mas Makmur sebanyak dua orang responden, dan kelompok ketiga yaitu Desa
Pangkal Mas Mulya sebanyak empat orang reponden.

Analisis dilakukan terhadap produksi yang dihasilkan dalam kurun waktu satu tahun terakhir atau dalam dua musim panen padi yaitu musim I pada saat musim panen rendeng (musim penghujan) dan musim II pada saat musim panen gado (musim kemarau). Pengusaha agroindustri juga menerima jasa penggilingan padi bagi petani dengan sistem bagi hasil. Data hasil perhitungan nilai tambah agroindustri di KTM Mesuji dapat dilihat pada Tabel 1 .

Berdasarkan Tabel 1 diketahui bahwa nilai tambah agroindustri yang menggunakan mesin secara keseluruhan dalam operasionalnya mempunyai nilai tambah yang lebih tinggi dibandingkan dengan agroindustri yang menggunakan mesin pada proses penggilingan saja. Hal tersebut disebabkan ketika agroindustri menggunakan bantuan cahaya matahari dalam kegiatan pengeringannya, maka agroindustri tersebut membutuhkan tenaga kerja tambahan yang berfungsi untuk membolak-balik gabah sehingga membutuhkan biaya tenaga kerja yang lebih banyak. 
Tabel 2. Perhitungan R/C agroindustri penggilingan padi di Kecamatan Mesuji Timur, 2019

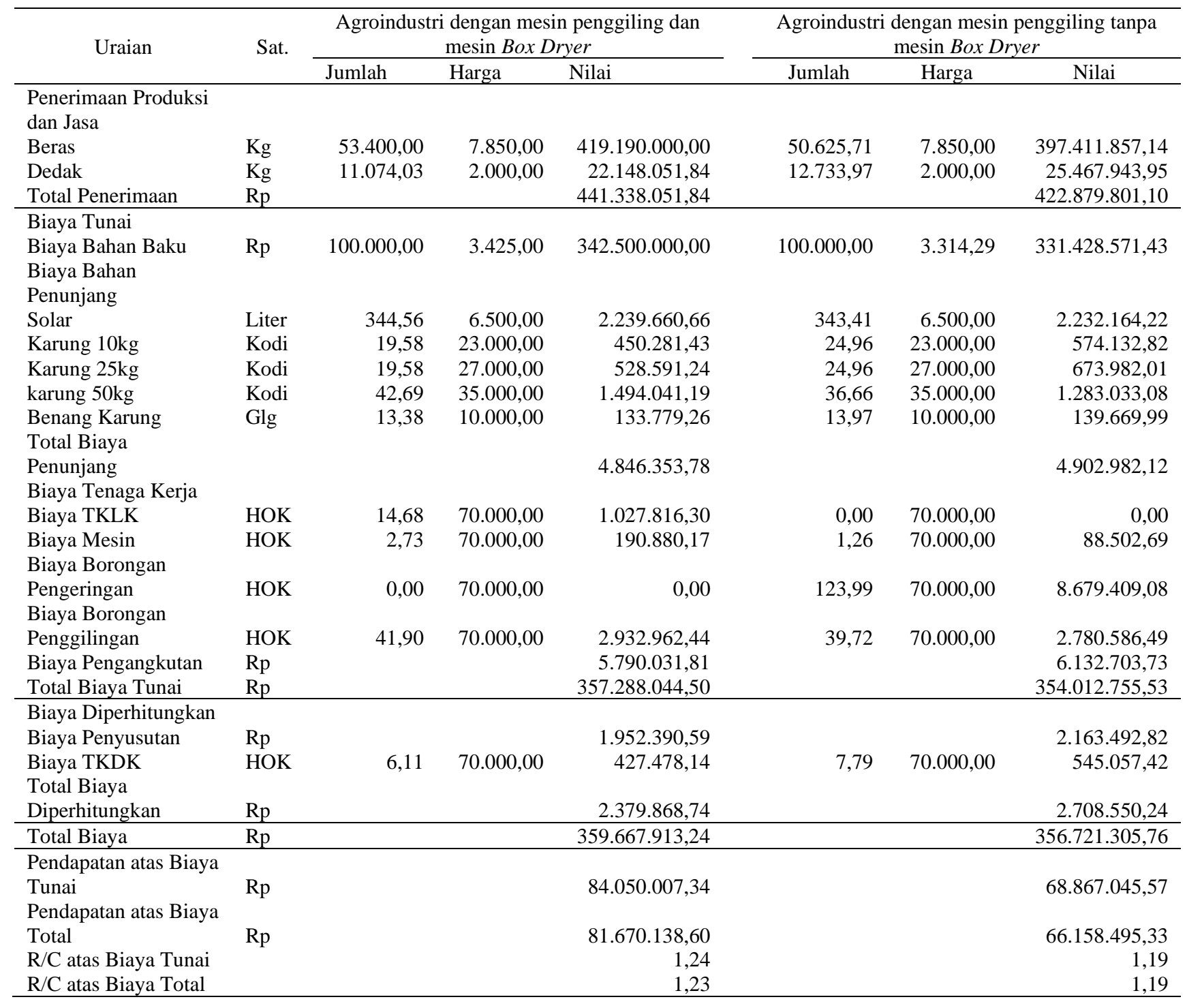

Berdasarkan Tabel 1 nilai tambah usaha penggilingan padi bernilai positif. sehingga usaha penggilingan padi ini layak untuk diusahakan. Hal ini senada dengan penelitian Novia, Zakaria, dan Lestari (2013) yang menyatakan nilai tambah yang memiliki nilai positif menyebabkan sebuah usaha layak untuk dikembangkan dan nilai tambah masih dapat ditingkatkan.

Rata-rata HOK dalam kegiatan penggilingan dan pengeringan pada agroindustri yang menggunakan mesin secara keseluruhan sebesar 50 HOK. Penggunaan HOK lebih sedikit karena pengerjaan agroindustri lebih banyak menggunakan mesin sehingga penggunaan tenaga kerja manusia lebih diminimalisir. Agroindustri yang menggunakan mesin pada saat penggilingan saja sebesar 103 HOK. Faktor konversi pada agroindustri yang menggunakan mesin secara keseluruhan sebesar 0,53 , sedangkan agroindustri yang menggunakan mesin pada penggilingan saja sebesar 0,51 perkilogram bahan baku. Berdasarkan nilai tersebut menyebabkan nilai tambah agroindustri pengguna mesin secara keseluruhan sebesar Rp629,97 per kilogram bahan baku, sedangkan untuk agroindustri yang menggunakan mesin hanya pada saat penggilingan sebesar Rp525,68 perkilogram bahan baku.

\section{Analisis Usaha Penggilingan Padi}

Analisis usaha bertujuan untuk mengetahui apakah usaha yang dijalankan menguntungkan dan layak untuk dikembangkan ataukah mengalami kerugian sehingga memerlukan evaluasi untuk mengembangkan usaha tersebut. Perhitungan hasil analisis $\mathrm{R} / \mathrm{C}$ usaha penggilingan padi dijabarkan pada Tabel 2. 
Berdasarkan Tabel 2, rata-rata penerimaan agroindustri penggilingan padi yang menggunakan mesin pada kegiatan pengeringan dan penggilingan sebesar Rp441.338.051,84 per $100.000 \mathrm{~kg}$ bahan baku, sedangkan pada agroindustri yang menggunakan mesin pada saat penggilingan saja sebesar Rp422.879.801,10 per $100.000 \mathrm{~kg}$ bahan baku. Besarnya penerimaan sebanding dengan total biaya yang dikeluarkan pengusaha untuk operasional agroindustrinya.

Nilai $\mathrm{R} / \mathrm{C}$ atas biaya tunai dan biaya total pada agroindustri yang menggunakan mesin pada kegiatan pengeringan dan penggilingan secara berturut-turut sebesar 1,24 dan 1,23, sedangkan nilai $\mathrm{R} / \mathrm{C}$ atas biaya tunai dan biaya total pada agroindustri yang hanya menggunakan mesin pada kegiatan penggilingan saja secara berturut-turut sebesar 1,19 dan 1,19. Nilai R/C pada kedua jenis agroindustri memiliki perbedaan. Perbedaan ini dikarenakan pendapatan yang didapatkan pengusaha agroindustri yang menggunakan mesin pada kegiatan pengeringan dan penggilingan lebih besar disebabkan biaya produksi yang digunakan lebih rendah dibandingkan dengan agroindustri yang hanya menggunakan mesin pada kegiatan penggilingan saja. Hasil tersebut dapat disimpulkan bahwa penggunaan mesin pada proses pengeringan dapat meningkatkan pendapatan bagi agroindustri penggilingan padi.

Nilai R/C pada agroindustri penggilingan padi di KTM Mesuji masih rendah jika dibandingkan dengan hasil penelitian Mamondol (2016) yang mendapatkan R/C mencapai 2,62 dengan komoditas yang sama. Penelitian serupa yang dinukil dari penelitian Saputro, Supardi, dan Ani (2018) mempunyai hasil yang sebanding dengan penelitian ini, dimana $\mathrm{R} / \mathrm{C}$ yang didapatkan sebesar 1,20 yang tidak jauh berbeda pada penelitian ini.

Nilai R/C menunjukkan bahwa agroindustri tersebut menguntungkan karena nilai $\mathrm{R} / \mathrm{C}$ lebih besar dari 1,00 dan layak untuk diusahakan. Nilai $\mathrm{R} / \mathrm{C}$ atas biaya tunai sebesar 1,24 dan $\mathrm{R} / \mathrm{C}$ atas biaya total sebesar 1,23 pada agroindustri yang menggunakan mesin pada kegiatan pasca panen menunjukkan bahwa setiap Rp1,00 biaya tunai dan biaya total yang dikeluarkan, agroindustri penggilingan padi dapat menghasilkan penerimaan sebesar Rp1,24 dan Rp23, sedangkan R/C atas biaya total sebesar 1,19 dan 1,19 pada agroindustri yang hanya menggunakan mesin pada kegiatan penggilingan saja menunjukkan bahwa setiap $\mathrm{Rp} 1,00$ biaya tunai biaya total yang dikeluarkan akan menghasilkan penerimaan sebesar Rp1,19 dan Rp1,19.

Besaran nilai R/C yang tidak terlalu besar inilah yang menjadi salah satu sebab mengapa petani enggan menjual hasil usahataninya dalam bentuk beras. Keuntungan yang diperoleh sangatlah kecil, namun biaya yang dikeluarkan tidak sedikit, sehingga petani yang juga membutuhkan modal untuk melanjutkan usahataninya lebih memilih untuk menjual hasil usahataninya dalam bentuk gabah kering panen langsung kepada agen.

\section{Rice Milling Plant (RMP) Kota Terpadu Mandiri Mesuji}

Gedung Rice Milling Plant atau yang lebih dikenal dengan sebutan RMP merupakan sebuah bangunan yang berasal dari bantuan pemerintah pusat Republik Indonesia kepada KTM Mesuji. Gedung RMP menampung hasil panen dari berbagai desa di Kabupaten Mesuji untuk kemudian diolah menjadi beras. Tujuan dari RMP ini adalah untuk memudahkan petani dalam mengelola hasil panen. RMP Kabupaten Mesuji memiliki beberapa peralatan yang cukup mumpuni antara lain adalah Box Dryer, Husker (mesin pemecah kulit gabah, mesin Polisher (mesin sosoh/pemutih beras) dan mesin convayor.

Tenaga kerja tetap di KTM ini berjumlah 3 orang dengan kriteria satu orang bertugas sebagai operator dan penanggung jawab diseluruh bagian mesin-mesin yang ada di RMP. Dua orang lainnya bertugas untuk pekerjaan lainnya yang ada di RMP. Upah pekerja lepas dalam satu hari sebesar Rp80.000,00, sedangkan untuk pegawai tetap gaji dibayarkan oleh pengelola KTM di Dinas Ketahanan Pangan Mesuji.

Pemasaran juga terbilang cukup mudah dikarenakan di seberang dari gedung RMP adalah gudang bulog yang menerima produksi beras dari berbagai desa di Kabupaten Mesuji untuk disebarkan ke berbagai daerah. Biaya yang dipatok untuk jasa pengeringan di RMP Mesuji sebesar Rp250.000,00 per ton gabah kering panen, sedangkan untuk biaya penggilingan sebesar Rp150.000,00 per ton gabah kering giling.

Pemasaran pada dasarnya tidak terpaku melalui bulog, secara mandiri pihak RMP juga sudah menjual beras-berass yang dimilikinya kepada agen-agen yang kekurangan stok beras. Produk dari RMP sudah memiliki label tersendiri, hal itu 
tergambar jelas dalam karung yang tertera nama "Beras Petani Mesuji" yang merupakan nama produk dari RMP Kabupaten Mesuji.

Permasalahan yang terjadi pada saat penelitian berlangsung, RMP mengalami masa vakum disebabkan kekosongan pengelola RMP Mesuji dari pihak dinas. Kekosongan jabatan ini sudah berlangsung sejak Tahun 2018, sehingga tidak ada aktifitas yang dapat diamati dari RMP pada saat penelitian. Akses yang sulit terhadap RMP juga menyebabkan para petani enggan untuk mengelola kegiatan pasca panen padi mereka di RMP, selain itu juga pengolahan pasca panen harus melalui ketua kelompok tani.

Sebagai perawatan dan menjaga agar mesin-mesin yang ada tidak rusak, maka operator yang bertugas menjaga gedung ini dalam satu minggu setidaknya menghidupkan mesin sebanyak dua kali, agar mesin tidak benar-benar vakum dan mati total yang dapat menyebabkan mesin rusak, selain itu pihak operator juga menerima jasa penggilingan dalam jumlah kecil sebagai tambahan biaya perawatan mesin.

\section{KESIMPULAN}

Penanganan pasca panen sebagian besar tidak dilakukan oleh petani padi di KTM Mesuji, namun lebih banyak dilakukan oleh agroindustri penggilingan padi. Penanganan pasca panen yang dilakukan oleh petani terbatas hanya sampai pengangkutan saja. Penanganan pasca panen sudah baik, selain itu juga teknologi yang digunakan petani sudah moderen sehingga memudahkan kegiatan panen dan pasca panen. Besaran biaya pasca panen yang harus dibayarkan petani paling tinggi terdapat pada kegiatan pengangkutan hasil panen, sedangkan biaya pasca panen tertinggi yang harus dikeluarkan agroindustri penggilingan padi terdapat pada kegiatan penggilingan. Keseluruhan biaya panen dan pasca panen jika dilakukan oleh petani secara mandiri sebesar Rp3.513.359,97. Rata-rata nilai tambah dari proses pengeringan dan penggilingan gabah hasil panen masih rendah, namun nilai tambah bernilai positif sehingga agroindustri penggilingan padi layak untuk diusahakan.

\section{DAFTAR PUSTAKA}

Badan Pusat Statistik Lampung. 2012. Provinsi Lampung dalam angka 2012. Badan Pusat
Statistik. Lampung. 2017. Provinsi Lampung dalam angka 2017. Badan Pusat Statistik. Lampung. . 2018. Provinsi Lampung dalam angka 2018. Badan Pusat Statistik. Lampung.

Buditama L, Yuniati A, Nurmayani. 2017. Pelaksanaan program kota terpadu mandiri dalam kerangka otonomi daerah di Kabupaten Mesuji Lampung. Jurnal HIMA HAN. 4(2). https://jurnal.fh.unila.ac.id/in dex.php/han1/article/ view/1088/917. [17 Desember 2019]

Firdaus AY, Arizona Y, 2013. Penerapan kriteria clear dan clean dalam penyediaan tanah pada pembangunan kawasan transmigrasi kota terpadu mandiri di Provinsi Sulawesi Tengah. FPP-HUMA-YMP-PATRI. Sulawesi Tengah.

Hayami Y, Kawagoe T, Morooka Y, Siregar M. 1987. Agricultural marketing and processing in upland java a perspective from a Sunda Village. CPGRT Center. Bogor.

Mamondol. 2016. Analisis kelayakan ekonomi usahatani padi sawah di Kecamatan Pamona Puselemba. Jurnal Envira. 1(2). https://osf.io/preprints/inarxiv/gujx8/ Januari 2020].

Nazir M. 2011. Metode penelitian. Cetakan 6. Ghalia Indonesia. Jakarta.

Novia W, Zakaria WA, Lestari DAH. 2013. Analisis nilai tambah dan kelayakan pengembangan agroindustri beras siger. Jurnal Ilmu Ilmu Agribisnis. 1(3): 210-217. http://jurnal.fp.unila.ac.id/inde

x.php/JIA/article/view/575/537. [17 Desember 2019].

Republik Indonesia. Undang-undang Republik Indonesia No. 29 tahun 2009 tentang Perubahan Atas Undang-Undang No 15 Tahun 1997 tentang Ketransmigrasian.

Saputro AG, Supardi S, Ani SW. 2018. Analisis usaha agroindustri penggilingan padi kecil di Kabupaten Sragen. SEPA. 15(1):50-57. https://jurnal.uns.ac.id/sepa/article/view/2505 0/17694. [04 Januari 2020].

Sihombing DT, Simarauw J. 2015. Analisis nilai tambah rantai pasokan beras di Desa Tatengesan Kecamatan Pusomaen Kabupaten Minahasa Tenggara. Jurnal EMBA. 3(2):798805. https://ejournal.unsrat.ac.id/index.php/ emba/article/view/8902/8445. [17 Desember 2019].

Soekartawi. 2000. Pengantar agroindustri. PT Raja Grafindo Persada. Jakarta.

Sugiarto. 2003. Teknik sampling. Gramedia. Jakarta. 